\title{
RANCANG BANGUN DAN OPERASIONAL REAKTOR BIOGAS TIPE PORTABLE UNTUK MENGOLAH LIMBAH KOTORAN TERNAK SAPI
}

\author{
Rahmantio Fadil Saputra ${ }^{1^{*}}$ \\ ${ }^{1}$ Politeknik Kesehatan Kemenkes Tanjungkarang
}

\section{Artikel Info : \\ Received 13 Februari 2022 Accepted 24 Februari 2022 Available online 28 Februari 2022}

Editor: Mei Ahyanti

Keyword :

Biodigester, biogas, livestock, reactor, portable

Kata Kunci :

Biodigester, biogas, ternak, reaktor, portable

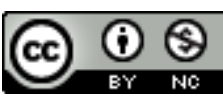

Ruwa Jurai: Jurnal Kesehatan Lingkungan is licensed under a Creative Commons AttributionNonCommercial 4.0 International License.

\begin{abstract}
A bstract
Livestock dung is waste generated from livestock which often disturbs health, environment, and aesthetics if not appropriately managed. This study aims to design a portable type biogas reactor to process cow dung waste into biogas products by adding bio activator effective microorganism4 (EM4) and molasses to test the effectiveness of the rate of biogas formation in a portable biogas reactor. The experiment started with making a portable biogas reactor, then tested by adding cow dung into the biodigester. The clean cow dung is mixed with water in a ratio of 1:1, then livestock EM4 $(100 \mathrm{ml})$ and molasses $(400 \mathrm{ml})$ are added. Observations for 15 days and measurements were made of temperature, $\mathrm{pH}$, pressure, and flame. The results of biogas formation are $15 \mathrm{~kg} / \mathrm{cm}^{2}$ or $1,132 \mathrm{~m}^{3}$, with the highest temperature of $28.4^{\circ} \mathrm{C}$ and the lowest

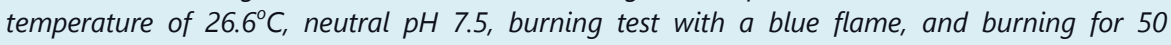
minutes. The biogas design can operate properly. During operation, the average digester temperature was $27.48^{\circ} \mathrm{C}$ (26.6-28.4), and $\mathrm{pH}$ was 7.5. The rate of gas formation significantly increased from the fifth day and produced a blue flame for 50 minutes at a pressure of 15 $\mathrm{kg} / \mathrm{cm}^{2}$.
\end{abstract}

Kotoran ternak adalah limbah yang dihasilkan dari berternak sering mengganggu kesehatan, lingkungan, dan estetika, jika tidak dilakukan pengelolaan. Penelitian bertujuan membuat rancang bangun reaktor biogas tipe portable untuk mengolah limbah kotoran sapi menjadi produk biogas dengan menambahkan bioaktivator effective mikcroorganism-4 (EM4) dan tetes tebu guna menguji efektivitas laju pembentukan biogas pada reaktor biogas tipe portable. Eksperimen diawali dengan pembuatan reaktor biogas tipe portable, kemudian diujicobakan dengan memasukkan kotoran sapi ke dalam biodigester. Kotoran sapi yang telah bersih dicampur air dengan perbandingan 1:1, kemudian ditambahkan EM4 peternakan (100 ml) dan tetes tebu (400 ml). Pengamatan dilakukan selama 15 hari, dan dilakukan pengukuran suhu, $\mathrm{pH}$, tekanan, dan nyala api. Hasil pembentukan biogas yaitu $15 \mathrm{~kg} / \mathrm{cm}^{2}$ atau $1.132 \mathrm{~m}^{3}$, dengan suhu tertinggi $28,4^{\circ} \mathrm{C}$ dan suhu terendah $26,6^{\circ} \mathrm{C}, \mathrm{pH}$ netral 7,5 , uji pembakaran dengan warna api biru dan menyala selama 50 menit. Rancang bangun biogas mampu beroperasi dengan baik. Rata-rata suhu digester selama beroperasi $27,48{ }^{\circ} \mathrm{C}(26,6-28,4)$, dan pH 7,5. Laju pembentukan gas secara signifikan meningkat mulai hari kelima, dan menghasilkan api biru selama 50 menit pada tekanan $15 \mathrm{~kg} / \mathrm{cm}^{2}$.
* Corresponding author: Rahmantio Fadil Saputra

Jl. Soekarno-Hatta No 6, Bandar Lampung, Lampung. Indonesia.

Email: rahmantiof@gmail,com

\section{PENDAHULUAN}

Struktur sosial peternak khususnya peternak sapi di Indonesia merupakan usaha sampingan sehingga skala kepemilikan ternak berkisar 3-4 ekor per rumah tangga (Said, 2018). Kegiatan manusia, termasuk beternak, menghasilkan limbah yang masih dapat dimanfaatkan (Kartono, 2010). Limbah yang dihasilkan dari usaha peternakan bervariasi bentuknya, ada yang berupa padat, cair, maupun gas. Limbah 
padat diantaranya adalah feses, sisa pakan, kulit, tulang, lemak, dan lain-lain. Limbah cair diantaranya adalah urine dan air, baik yang digunakan untuk air minum maupun air untuk pembersih kandang. Limbah berupa gas terdiri atas amonia, sulfur, metana, karbon dioksida, dan H,S. Limbah-limbah ini jika tidak dilakukan penanganan secara serius akan mengakibatkan pencemaran lingkungan (air, tanah, maupun udara) yang berbahaya bagi manusia, ternak, maupun tanaman disekitarnya (Triatmojo, Erwanto, \& Fitriyanto, 2016).

Limbah padat, seperti kotoran ternak yang bercampur dengan sisa pakan sering dijumpai di lingkungan sekitar. Menurut Kartono (2010) selama ini pemanfaatan dari kotoran ternak dan sisa pakan untuk pupuk kandang atau campuran dalam pembuatan kompos bertujuan menyuburkan tanaman, namun bila tidak segera dimanfaatkan maka menimbulkan bau yang tidak sedap dan dapat menimbulkan penyakit seperti diare dan typhus.

Setiap seekor sapi potong induk dengan bobot $500 \mathrm{~kg}$ mempunyai 5 animal population unit (APU) dan jumlah ternak setiap APU nya adalah $100 / 5=0,20$, bila sebuah peternakan sapi potong memelihara 5 ekor sapi dengan rincian 1 ekor sapi jantan kastrasi dan 4 ekor sapi potong induk, maka nilai APU nya $=1 \times 3+4 \times 5$ = 23 APU. Bila, 1 ekor sapi dewasa menghasilkan kotoran sapi sekitar $20 \mathrm{~kg} /$ hari. Maka jumlah manure atau kotoran ternak yang dihasilkan oleh peternakan tersebut adalah $23 \times 20=460$ $\mathrm{kg} / \mathrm{hari}$.

Apabila limbah ternak sebanyak $460 \mathrm{~kg} /$ hari dibuang ke sungai dengan kandungan bahan organik yang tinggi dapat menghabiskan kandungan oksigen air, sehingga menyebabkan terjadinya kondisi anaerob dan menimbulkan bau busuk sebagai akibat dari perombakan bahan organik secara anaerob. Kandungan mikroba patogen yang terdapat pada limbah ternak dapat mengancam kesehatan manusia karena di dalamnya mengandung banyak bakteri penyebab penyakit seperti $E$. Coli dan Enterobacter cloacae, berbagai virus, dan cacing. Kandungan unsur hara nitrogen, fosfor, kalium yang terakumulasi dalam air sungai menyebabkan terjadinya ledakan kandang dapat mencemari air sumur yang ada di dekatnya
(Triatmojo et al., 2016). Di sisi lain, proses pembakaran kotoran sapi yang dilakukan oleh masyarakat dapat menghasilkan gas-gas berbahaya, karena kotoran sapi mengandung gas amonia, karbon dioksida, karbon monoksida, dan gas metana. Gas metana yang terbakar dapat menghasilkan gas karbon dioksida, sehingga jumlah karbon dioksida di udara akan meningkat dan menimbulkan terjadinya efek rumah kaca. Gas hasil pembakaran juga sangat berbahaya jika terhirup oleh manusia (Zein, Purnomo, Ariani, Meliana, \& Andriyani, 2019).

Belum ada lembaga atau pun perorangan untuk pengelolaan kotoran sapi di daerah peternakan di Kabupaten Tulang Bawang Provinsi Lampung. Sehingga yang terjadi adalah limbah tersebut dibiarkan begitu saja tanpa adanya pengelolaan lebih lanjut. Padahal potensi kotoran sapi sebagai bahan pembuatan biogas sebenarnya cukup besar namun belum banyak dimanfaatkan (Said, 2018).

Perlu adanya treatment atau cara pengelolaan yang lebih efektif untuk menanggulangi limbah ternak tersebut, selain dari pengolahan menjadi pupuk kandang atau bahan campuran pembuatan kompos yang dirasa kurang efektif dalam mengurangi tumpukan limbah ternak. Berdasarkan pendapat penulis di atas, penulis bertujuan melakukan penelitian pembuatan reaktor digester untuk pengelolaan limbah kotoran sapi menjadi produk biogas dengan menambahkan bioaktivator effective microorganism-4 (EM4) dan tetes tebu guna mengetahui efektivitas laju pembentukan biogas pada alat tipe portable. EM4 berfungsi sebagai activator mikroorganisme sedangkan tetes tebu menyuburkan mikroba.

\section{METODE}

Penelitian ini merupakan eksperimen yang bertujuan membuat rancang bangun reaktor biogas portable, dengan bahan baku kotoran sapi. Penelitian ini dilaksanakan dari bulan Maret-April 2021, di Desa Wiratama, Kecamatan Penawartama, Kabupaten Tulang Bawang. Pembuatan digester dengan memanfaatkan drum fiberglass dan tripleks.

Sebelum dimasukkan ke dalam biodigester kotoran sapi yang telah bersih dicampur air dengan perbandingan 1:1 (100 kg kotoran sapi 
dan 100 liter air sumur). Ke dalam campuran ditambahkan EM4 peternakan dan tetes tebu (100 $\mathrm{ml}$ EM4 dan $400 \mathrm{ml}$ tetes tebu). Tetes tebu memiliki fungsi sebagai nutrisi bagi mikroba dan mempercepat proses fermentasi. Sedangkan substrat EM4 peternakan dan tetes tebu untuk mendukung pembentukan biogas pada reaktor. Suhu dikondisikan pada suhu $20^{\circ} \mathrm{C}$ sampai $30^{\circ} \mathrm{C}$ agar bakteri bekerja secara optimal. Perubahan suhu akan diketahui melalui termometer digital yang dipasang pada alat digester anaerob, serta dilakukan pengecekan setiap hari. Pengukuran $\mathrm{pH}$ dilakukan di awal (saat bahan baku dimasukkan), dan di akhir proses (hari ke 15). Pengukuran tekanan biogas dilakukan dengan melihat angka yang ditunjukkan oleh manometer yang diukur tiap hari pada tangki. Lama nyala api dihitung dengan melihat lamanya waktu yang terpakai pada kompor gas mulai dari api menyala hingga api mati.

\section{HASIL}

\section{Suhu}

Dari lama proses fermentasi kotoran sapi didapat hasil pengukuran suhu selama 15 hari. Proses pengukuran suhu digester dilakukan setiap jam 10:00 WIB. Pada saat proses penelitian sedang terjadinya transisi atau pergantian musim penghujan ke musim kemarau. Sehingga mengakibatkan kondisi suhu biodigester juga ikut mengalami naik turun. Ratarata suhu pada $27,48^{\circ} \mathrm{C}$, suhu terendah dalam digester berada pada angka $26.6^{\circ} \mathrm{C}$ dan suhu tertinggi dalam digester berada pada angka $28,4^{\circ} \mathrm{C}$

2. $\mathrm{pH}$

Pengukuran $\mathrm{pH}$ dilakukan pada saat proses memasukkan bahan baku serta saat mengeluarkan bahan baku yang telah menjadi lumpur. Hasil pengukuran awal diperoleh $\mathrm{pH}$ yaitu 7,5 dan pada akhir proses akhir diperoleh $\mathrm{pH} \mathrm{7,5.}$

\section{Laju Pembentukan biogas.}

Dari hasil pengukuran laju pembentukan biogas didapat bahwa adanya pelambatan pembentukan biogas pada hari ke-8 hingga hari ke-11.

Dilihat dari proses pembentukannya kenaikan tekanan biogas yang signifikan yaitu pada hari ke-5 hingga hari ke-8 atau pada minggu pertama, lalu pada minggu selanjutnya proses tetap mengalami kenaikan tekanan.

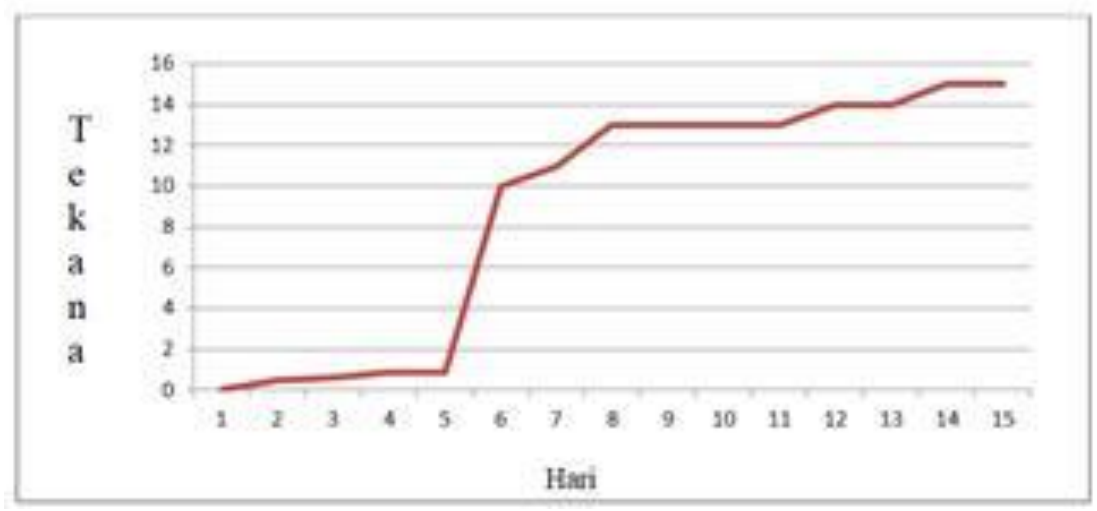

Gambar 1. Laju proses pembentukan biogas.

\section{Lama Nyala Api}

Pengujian nyala api dilakukan pada tangki biodigester pada kapasitas maksimum 15 $\mathrm{kg} / \mathrm{cm}^{2}$. Alat yang digunakan sebagai tempat keluar nya gas untuk diuji coba menggunakan nozzle berdiameter $1 \mathrm{~cm}$. Api yang dikeluarkan berwarna biru. Hal ini disebabkan kandungan gas yang dihasilkan telah homogen didalam biodigester dan tidak ada bau yang menyengat pada saat gas keluar dari tangki biodigester. Pada uji pembakaran, gas dalam biodigester baru mampu menyalakan api selama 50 menit.

\section{PEMBAHASAN}

1. Rancang bangun digester

Jenis reaktor yang digunakan dalam penelitian ini adalah reaktor floating drum. Keuntungan dari reaktor ini adalah dapat 
melihat secara langsung volume gas yang tersimpan pada drum karena pergerakannya, bahan yang dimaksud pada jenis reaktor ini berupa fiberglass atau drum kaleng sehingga banyak industri dan rumah tangga yang menggunakan reaktor ini sebagai tempat pembuatan biogas.

Jenis biodigester floating drum sudah banyak di kembangkan oleh peneliti sebelumnya, dengan variasi volume $2,5 \mathrm{~m}^{3}$ hingga $6 \mathrm{~m}^{3}$. Selain itu, hasil yang telah didapat menggunakan jenis biodigester ini tidak kalah apabila dibandingkan dengan jenis fix dome, floating dome, dan reaktor balon dengan variasi lama fermentasi yang di terapkan, sehingga peneliti ingin menyempurnakan jenis biodigester floating dome yang telah ada dengan penambahan substrat guna mendapatkan laju pembentukan hasil gas metana yang lebih cepat dengan lama nyala api yang lebih lama.

Alasan menggunakan jenis reaktor tipe ini adalah kedap udara, ringan serta kuat. Selain itu apabila ada kerusakan atau kebocoran gas pada digester mudah dilakukan pengecekan serta perbaikan. Digester ini juga dapat dibentuk kembali seperti semula apabila terjadi kerusakan atau produksi gas dalam digester mengalami penurunan, dan dapat dipindahkan sewaktu waktu apabila tidak digunakan kembali.
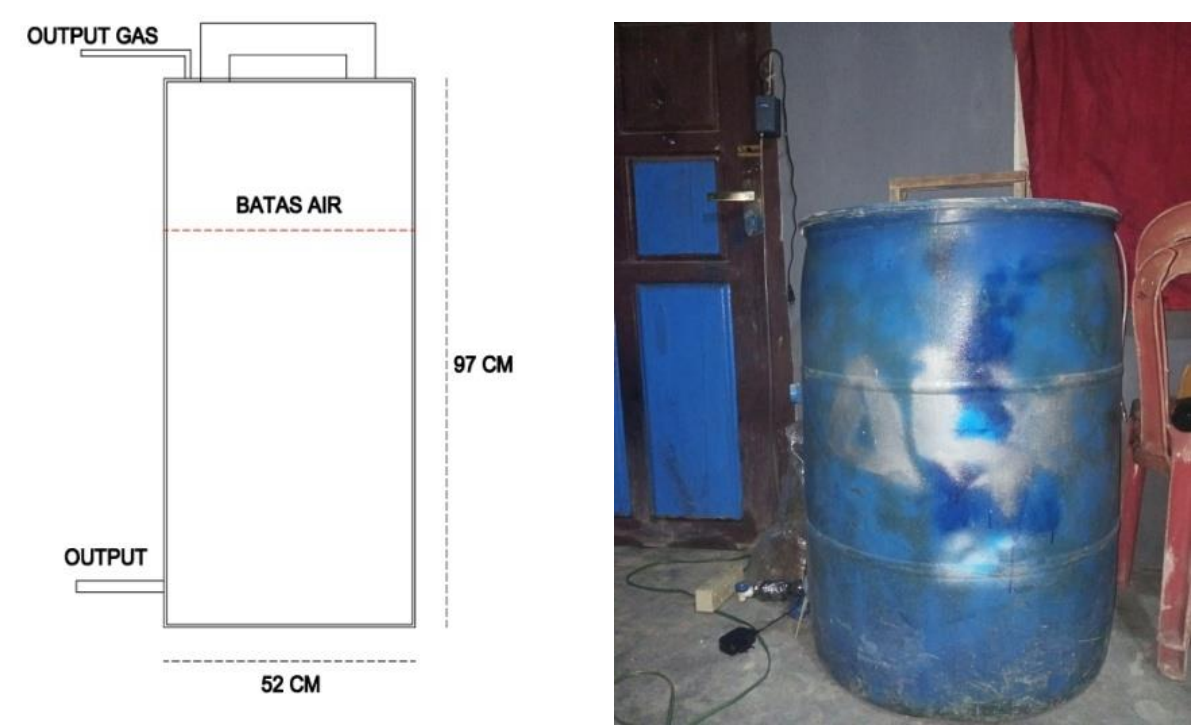

Gambar 2. Rancang bangun digester portable

Pada tahap fermentasi, lingkungan atau kondisi digester harus pada posisi anaerob atau tidak adanya kontak oksigen terhadap ruang anaerob pada digester. Apabila oksigen dapat masuk kedalam digester, hal ini menandakan digester mengalami kebocoran dan produksi gas metana yang dihasilkan rendah. Bakteri yang bekerja didalam digester adalah bakteri anaerob yang membutuhkan kondisi yang kedap udara sehingga jika ada sedikit oksigen yang masuk maka bakteri tidak dapat bekerja secara optimal. Saat sebelum tangki pencerna digunakan sebaiknya dilakukan pengecekan kebocoran untuk mengurangi adanya kegagalan, dengan cara mengisi tangki dengan air hingga penuh lalu diamati setiap bagian untuk mengetahui ada atau tidaknya kebocoran pada tangki pencerna.

Pada penelitian ini penambahan bahan tambahan untuk bahan baku biogas menggunakan EM4 dan hasil fermentasi dari limbah tebu yaitu molase, penggunaan EM4 sebanyak $400 \mathrm{ml}$ dan molaes sebanyak $100 \mathrm{ml}$. tujuan penggunaan kedua bahan ini yaitu melihat laju pembentukan biogas yang dihasilkan dengan kurun waktu 15 hari.

Proses pembuatan yang pertama yaitu menyiapkan bahan baku terlebih dahulu yaitu kotoran sapi seberat $100 \mathrm{~kg}$ dan 100 liter air sumur atau air bersih lainnya, lalu di lakukan pencampuran dari kedua bahan tersebut sambil diaduk sampai berbentuk seperti bubur, setelah 
itu dituangkan bahan tambahan yaitu EM4 sebanyak $400 \mathrm{ml}$ serta molase $100 \mathrm{ml}$, setelah seluruh bahan dimasukkan lalu diaduk kembali sampai dirasa telah tercampur sempurna, setelah itu bio-digester ditutup dengan rapat sehingga oksigen tidak dapat masuk kedalam digester karena hal tersebut dapat mempengaruhi kinerja bakteri anaerob untuk memfermentasi bahan organik dalam kotoran sapi.

\section{Suhu}

Suhu yang tinggi mempengaruhi pembentukan biogas semakin baik. Namun suhu tersebut baiknya tidak melebihi suhu di ruangan, suhu yang baik untuk proses pembentukan biogas antara $20-40^{\circ} \mathrm{C}$ dan suhu optimum antara 28 $30^{\circ} \mathrm{C}$ (Wicaksono, Amalia, Elvian, \& Prasetya, 2019).

Semakin tinggi temperatur reaksi maka bakteri akan membentuk gas metana semakin cepat namun juga akan mempercepat pengurangan jumlah bakteri. Suhu pada ruangan dapat mempengaruhi reaktor biogas. Agar dapat bekerja secara optimal selama proses digesti anaerob, bakteri memerlukan kondisi temperature $20-40^{\circ} \mathrm{C}$ (Sasongko, W, 2010; Santoso, A. A, 2010; Wahyuni, S. M, 2013). Laju produksi gas metana meningkat dengan meningkatnya suhu,tetapi produksi gas akan turun secara drastis apabila berada dibawah suhu $10^{\circ} \mathrm{C}$ karena pada suhu ekstrim tinggi atau terlalu rendah bakteri metanaogen berada dalam kondisi tidak aktif.

Selama proses penelitian perubuhan suhu ruangan mengalami kondisi naik turun, ini disebabkan karena kondisi cuaca di lingkungan penelitian sedang mengalami transisi musim hujan ke musim kemarau sehingga hal tersebut mempengaruhi suhu didalam biodigester, dilihat dari kondisi tersebut didapatkan hasil suhu terendah yaitu $26,6^{\circ} \mathrm{C}$ dan suhu tertinggi yaitu $28^{\circ} \mathrm{C}$. Berdasarkan kondisi temperaturnya, bakteri yang berperan dalam proses fermentasi secara anaerob dibagi menjadi 3, yaitu Bakteri psychrophilic yang hidup di temperatur $8^{\circ} \mathrm{C}$ sampai $25^{\circ} \mathrm{C}$, Bakteri mesophilic yang hidup pada temperatur $35^{\circ} \mathrm{C}$ sampai $37^{\circ} \mathrm{C}$ dan Bakteri thermophilic yang hidup pada temperatur optimum $53^{\circ} \mathrm{C}$ sampai $55^{\circ} \mathrm{C}$ (Triatmojo et al., 2016). Jika dikaitkan dengan hasil suhu yang didapat selama proses fermentasi, bakteri yang berperan dalam proses fermentasi dapat hidup pada penelitian ini. Dari hasil penilitian ini didapatkan hasil suhu rata-rata yang keluar berada di $26^{\circ} \mathrm{C}$ hingga $27^{\circ} \mathrm{C}$ sehingga proses digesti anaerob dapat berjalan dengan baik.

3. $\mathrm{pH}$

Bila proses fermentasi berlangsung dalam keadaan normal dan anaerob, maka $\mathrm{pH}$ lebih tinggi dari 8,5 akan mengakibatkan pengaruh yang negatif pada populasi bakteri metanaogen, sehingga akan mempengaruhi laju pembentukan biogas dalam reaktor (Budiyono, Khaerunnisa, \& Rahmawati, 2013). Bakteri metanaogen sensitif terhadap $\mathrm{pH}$ tertentu dan cenderung tidak dapat hidup jika berada pada $\mathrm{pH}$ dibawah 6,6 . Nilai $\mathrm{pH}$ untuk digesti anaerobik adalah 6,6 sampai 7,5 dengan $\mathrm{pH}$ optimum 7,0 sampai 7,2 (Triatmojo et al., 2016).

Disisi lain penambahan EM4 dapat menjaga kestabilan ph pada angka yang netral yaitu berkisar 6 sampai 7,5. Seperti penelitian yang telah dilakukan (Harwiyanti, 2006). Didapatkan hasil seluruh reaktor memiliki $\mathrm{pH}$ yang netral yaitu 6-7, $\mathrm{pH}$ tertinggi yaitu $\mathrm{pH}$ yang optimal berada pada angka 8. Sehingga dapat dikatakan bahwa penambahan EM4 memiliki peran dalam menjaga kestabilan $\mathrm{pH}$ yang ada di dakam digesti anaerob. Selain itu penambahan tetes tebu juga turut membantu menurunkan $\mathrm{pH}$ pada kotoran sapi, glukosa merupakan gula yang disukai oleh bakteri karbon dan bakteri asam laktat yang umumnya akan memecah glukosa untuk menghasilkan asam laktat, hal ini menyebabkan $\mathrm{pH}$ media menjadi rendah yang dapat menghambat pertumbuhan bakteri lain.

Pada penelitian ini sendiri diketahui tidak adanya kenaikan atau penurunan $\mathrm{pH}$ setelah dilakukan pengecekan. Pengecekan $\mathrm{pH}$ dilakukan pada tahap pemasukan bahan baku sampai di akhir penelitian, sebesar $\mathrm{pH}$ 7,5 dari proses digesti anaerob yang berlangsung selama 15 hari penelitian.

\section{Laju pembentukan biogas}

Pada hari ke-2 sudah tampak adanya kenaikan tekanan sebesar $0.5 \mathrm{~kg} / \mathrm{cm}^{2}$. Semakin bertambahnya hari, tekanan dalam biogas terus bertambah. Tekanan biogas yang semakin besar 
mengindikasikan bahwa biogas yang dihasilkan juga semakin banyak dan tekanan maksimal tercapai pada hari ke 15 yaitu $15 \mathrm{~kg} / \mathrm{cm}^{2}$. Tekanan dihasilkan dari proses fermentasi secara anaerob yang dihasilkan oleh bakteri metanaogen dalam menguraikan beberapa zat yang terkandung dalam kotoran sapi, dalam hal ini bakteri menguraikan limbah organik menjadi asam-asam organik sederhana (asam format, asetat, butirat, dan propionat).

Seperti layaknya proses biologi lainnya, digesti anaerobik memerlukan adanya kondisi lingkungan yang terkendali. Dalam memproduksi gas metana hal-hal yang berpengaruh adalah temperatur tabung reaktor, karena apabila temperatur rendah maka akan semakin lama waktu yang dibutuhkan untuk memproduksi gas metana. Selama proses fermentasi, pembentukan biogas mengalami kondisi naik turun yang disebabkan oleh aktivitas mikroorganisme di dalam reaktor, terlihat bahwa laju pembentukan gas terus naik pada hari ke-1 sampai ke-7 atau pada minggu pertama, lalu pada hari ke-8 sampai ke-11, seterusnya laju pembentukan gas mulai melambat. Hal tersebut mengindikasi bahwa pada minggu pertama tetes tebu telah bekerja menyuburkan mikroorganisme. Penambahan EM4 bekerja efektif untuk mendegradasi senyawa organik, kemudian pada mingguminggu selanjutnya produksi biogas semakin berkurang (Megawati \& Aji, 2015).

Penggunaan EM4 cenderung menyebabkan penurunan massa gas metana, penambahan EM4 dapat mengurangi rasio $C / N$ serta memperkecil massa biogas yang dihasilkan sebesar $29,032 \%$. Jika dilihat penelitian sejenis, kecepatan pembentukan biogas tersebut dipengaruhi oleh beberapa hal, salah satunya adalah kecepatan fermentasi bahan organik, namun pada minggu selanjutnya hingga selesai kecepatan pembentukan biogas pada variabel penambahan EM4 1\% mulai berkurang. Terlihat bahwa pada variabel penambahan EM4 $1 \%$ mencapai puncaknya pada minggu pertama. Hal tersebut mengindikasikan bahwa pada minggu pertama EM4 bekerja efektif untuk mendegradasi senyawa organik, kemudian pada mingguminggu selanjutnya produksi biogas semakin berkurang. Sedangkan pada variabel penambahan EM4 0\% mencapai puncaknya pada minggu ketiga. Sehingga dapat dikatakan bahwa pada dasarnya penggunaan EM4 digunakan untuk memenuhi keseragaman bakteri yang ada pada proses anaerob, namun disisi lain penggunaan EM4 tersebut mempengaruhi rasio $C / N$ sehingga mengurangi massa metana pada gas yang dihasilkan. Hal ini berpengaruh pada lama nyala api yang di hasilkan karena jika massa metana rendah maka nyala api juga semakin cepat.

Penelitian menggunakan substrat kotoran sapi sebanyak $100 \mathrm{~kg}$ dengan campuran air 100 $\mathrm{L}$, lalu ditambahkan EM4 sebanyak $100 \mathrm{ml}$ dan tetes tebu $400 \mathrm{ml}$. dari bahan-bahan tersebut di dapat hasil gas yang terkumpul sebanyak $15 \mathrm{~kg} / \mathrm{cm}^{2}$ yang mana bila diubah ke satuan $\mathrm{m}^{3}$ maka di dapat hasil 1,132 $\mathrm{m}^{3}$. Seharusnya dengan bahan-bahan tersebut, volume gas yang diperoleh sebesar $2,3 \mathrm{~m}^{3}$. Terlihat adanya pengurangan laju pembentukan gas metana dalam digester. Penurunan dapat terjadi karena dalam penelitian ini tangki tidak dilengkapi dengan pengaduk.

Untuk membantu proses fermentasi penggunaan sistem pengaduk sangat penting digunakan karena bertujuan untuk menyirkulasi bahan organik sehingga dapat kembali melalui bagian atas digester. Padatan yang terlalu pekat atau mengendap akan menghambat laju aliran gas yang terbentuk pada bagian bawah digester sehingga gas yang diproduksi menjadi lebih sedikit. Pengadukan sebaiknya tidak dilakukan secara cepat karena dapat menghambat kerja bakteri dalam melakukan proses digesti bahan organik. Lain halnya jika bahan organik yang digunakan untuk produksi biogas berasal dari bahan yang tidak mudah larut didalam air dan tidak membentuk stratifikasi, maka komponen pengaduk tidak di perlukan.

\section{Lama nyala api}

Lama nyala api dipengaruhi oleh jumlah massa biogas dan kandungan gas pada biogas. Semakin banyak kandungan $\mathrm{CH}_{4}$ dan jumlah massa biogas maka lama nyala api akan semakin lama (Wicaksono et al., 2019). Pengujian dilakukan pada saat volume gas pada tangki biodigester pada kapasitas maksimum yaitu $15 \mathrm{~kg} / \mathrm{cm}^{2}$. Nyala api dalam penelitian ini 
diujicobakan menggunakan nyala api maksimal ,didapatkan hasil bahwa untuk gas yang terdapat pada tangki biodigester di gunakan hingga habis yaitu selama 50 menit.

Alat yang digunakan sebagai tempat keluar nya gas untuk di uji coba menggunakan nozzle berdiameter $1 \mathrm{~cm}$, lalu api yang dikeluarkan berwarna biru ini dikarenakan kandungan gas yang dihasilkan telah homogen didalam biodigester dan tidak ada bau yang menyengat pada saat gas keluar dari tangki biodigester. Jika disandingkan dengan hasil penelitian sejenis (Putra, Abdullah, Priyati, Setiawati, \& Muttalib, 2017) yang menyatakan bahwa biodigester dengan kapasitas penyimpanan $0,19 \mathrm{~m}^{3}$ dapat menghasilkan nyala api 181 menit atau 3,01 jam, pada penilitian ini dengan menggunakan kapasitas yang sama didapat hasil nyala api selama 50 menit. Hasil ini belum maksimal, diduga karena tidak melakukan uji kebocoran dan tidak menggunakan pengaduk.

Dalam pembangunan biodigester harus ada perencanaan yang matang sehingga dapat menghasilkan gas yang diinginkan. Lingkungan sekitar biodigester berpengaruh dalam proses pembentukan gas metana yang ada di dalam biodigester (Sasongko, W, 2010; Santoso, A. A, 2010; Wahyuni, S. M, 2013). Biodigester harus tetap dijaga dalam keadaan anaerob (tanpa adanya kontak oksigen) karna dapat menyebabkan penurunan produksi gas metana, harus dilakukan uji kebocoran pada biodigester yang akan digunakan dengan cara mengisi tangki biodigester menggunakan air setelah itu diamati seluruh bagian pada tangki, apabila terjadi kebocoran dapat dilakukan penambalan atau menutup lubang yang terdapat pada tangki jika menggunakan tangki fiberglass bisa menggunakan lem atau dempul dan bila menggunakan tangki seng atau besi dapat dilakukan pengelasan jika terjadi kebocoran. Suhu digester berada pada $20-30^{\circ} \mathrm{C}$, bakteri yang berperan dalam proses penguraian atau fermentasi secara anaerob sensitif terhadap suhu lingkungan tangki digester, apabila lingkungan memiliki suhu yang sangat rendah atau sangat tinggi maka proses fermentasi dapat terganggu, maka perlu perencanaan pemilihan tempat untuk tangki digester agar proses anaerob dapat berlangsung secara optimal dengan suhu berkisar antara $20^{\circ} \mathrm{C}-30^{\circ} \mathrm{C}$, rasio $\mathrm{C} / \mathrm{N}$ yang ideal adalah 25-30, untuk mendapatkan rasio yang ideal maka penambahan bahan yang mengandung karbon seperti molase atau tetes tebu dapat dilakukan untuk mendapatkan rasio yang ideal. Selain lingkungan sekitar digester, perencanaan bentuk tangki digester juga harus diperhatikan. Pada penelitian ini bentuk tangki digester tidak dilengkapi dengan sistem pengaduk, proses pengadukan dilakukan untuk mendapatkan campuran substrat yang homogen dengan ukuran partikel yang kecil. Pengadukan juga memberikan kondisi temperatur yang seragam dalam biodigester, sehingga pada sistem pengadukan sangat penting pada tangki biodigester dengan menggunakan bahan baku kotoran ternak yang sulit larut serta membentuk stratifikasi di dalam tangki.

\section{SIMPULAN}

Pembuatan tangki biodigester menggunakan drum berbahan fiberglass dengan tinggi $92 \mathrm{~cm}$ dan lebar $52 \mathrm{~cm}$ ini menggunakan waktu fermentasi 15 hari baru menghasilkan gas bio yang dapat menyala selama 50 menit. Hasil ini belum maksimal, diduga karena tidak melakukan uji kebocoran dan tidak menggunakan pengaduk. Perancangan digester akan lebih baik apabila memiliki sistem pengaduk, ini berguna untuk memudahkan kerja organisme untuk mendegradasi bahan organik yang ada didalam biodigester, penggunaan sistem pengaduk sendiri untuk menyirkulasi bahan organik ke bagian atas digester, maka perlu adanya pengembangan tangki biodigester untuk peneliti selanjutnya. Pada penambahan substrat tambahan yang akan digunakan, penggunaan tetes tebu dapat digunakan sebagai bahan alternatif dalam memenuhi karbon bagi mikroorganisme untuk menunjang laju pembentukan biogas bagi peneliti selanjutnya.

\section{DAFTAR PUSTAKA}

Budiyono, Khaerunnisa, G., \& Rahmawati, I. (2013). Pengaruh $\mathrm{pH}$ dan Rasio COD:N Terhadap Produksi Biogas dengan Bahan Baku Limbah Industri Alkohol (Vinasse). Eksergi, 11(1), 1. https://doi.org/10.31315/e.v11i1.324.

Harwiyanti, Y. (2006). PENGARUH PENAMBAHAN 
EM4 (Effective Mikroorganisme) TERHADAP PENGOMPOSAN BLOTONG. Jogjakarta: Universitas Islam Indonesia.

Kartono, S. (2010). Biogas Kotoran Ternak. Alprim Finishing: Semarang.

Megawati, \& Aji, K. W. (2015). Pengaruh Penambahan Em4 (Effective Microorganism-4) Pada Pembuatan Biogas Dari Eceng Gondok dan Rumen Sapi. Jurnal Bahan Alam Terbarukan, 3(2), 42-49. https://doi.org/10.15294/jbat.v3i2.3696

Putra, G. M. D., Abdullah, S. H., Priyati, A., Setiawati, D. A., \& Muttalib, S. A. (2017). Rancang Bangun Reaktor Biogas Tipe Portabel Dari Limbah Kotoran Ternak Sapi. Jurnal Ilmiah Rekayasa Pertanian Dan Biosistem, 5(1), 369-374.

Said, S. (2018). Membuat Biogas Dari Kotoran Hewan. Bentara Cipta Prima: Jakarta.

Santoso, A. A. (2010). Produksi Biogas Dari Limbah Rumah Makan Melalui Peningkatan Suhu dan Penambahan Urea Pada Perombakan Anaerob. Surakarta: Universitas Sebelas Maret.
Sasongko, W. (2010). Produksi Biogas Dari Biomassa Kotoran Sapi dalam Biodigester Fix Dome dengan Pengenceran dan Penambahan Agitasi. Surakarta: Universitas Sebelas Maret.

Triatmojo, S., Erwanto, Y., \& Fitriyanto, N. A. (2016). Penanganan Limbah Industri Peternakan. Yogyakarta: Gadjah Mada University Press. https://repository.ugm.ac.id/id/eprint/273197

Wahyuni, S. M. . (2013). Biogas. Jakarta: Penebar Swadaya.

Wicaksono, A., Amalia, R., Elvian, H., \& Prasetya, G. (2019). Pengaruh Penambahan EM4 Pada Pembuatan Biogas dengan Bahan Baku Kotoran Sapi Menggunakan Digester Fix Dome Sistem Batch. 2, 1-7.

Zein, I. N., Purnomo, N. Y., Ariani, W. D., Meliana, Y., \& Andriyani, R. (2019). Inovasi Pengolahan Kotoran Sapi. https://stikesbanyuwangi.ac.id/inovasipengolahan-kotoran-sapi-tim-pkmm/ (Diakses pada 30 Maret 2021) 